\title{
IMPLEMENTATION OF QR CODE ON E-CERTIFICATE FOR EVENTS AT MARANATHA CHRISTIAN UNIVERSITY
}

\author{
Bernard Renaldy Suteja $^{1)}$, Radiant Victor Imbar ${ }^{2)}$, Meliana Christianti Johan ${ }^{3)}$ \\ Fakultas Teknologi Informasi \\ Universitas Kristen Maranatha \\ J1. Surya Sumantri 65 Bandung \\ Email : ${ }^{1}$ bernard.rs@it.maranatha.edu
}

\begin{abstract}
Every participation in the activity is always proven by the presence of a certificate. Issuance of certificates requires fees for paper, printing and distribution. The emergence of the era of paper less should be able to transform the presence of the certificate. Paperless is stopped by the presence of digital documents that can be accessed independently (portable), easily and across platforms. Portable Document Format or abbreviated as PDF one of the popular documents that can be distributed via the internet. So that PDF can be used as a document base to realize e-Certificate. However, it is necessary to develop a good application to facilitate the presence of the e-Certificate, and present solutions related to the authenticity of the certificates produced.
\end{abstract}

Keywords : e-certificate, portable document, paper less.

\section{Pendahuluan}

Setiap keikutsertaan dari kegiatan selalu dibuktikan dengan hadirnya sebuah sertifikat. Penerbitan sertifikat membutuhkan adanya biaya untuk kertas, cetak dan distribusinya. Distribusi dilakukan dengan membagikan kepeserta - tentunya dengan adanya biaya kirim, dan bisa juga dilakukan dengan peserta mengambil sendiri ke sekretariat. Hasil dari pengamatan pada Unit dan Lembaga di lingkungan Universitas Kristen Maranatha masih banyak yang tidak mengambil sertifikat tersebut. Peserta dalam hal ini adalah Mahasiswa baru akan peduli dan mengambil saat dibutuhkan untuk melengkapi suatu syarat. Sehingga Unit dan Lembaga sering menyimpan sertifikat yang sudah dicetak untuk kurun waktu yang lama. Akibatnya ketika diambil kondisi tersebut sudah kurang baik dan atau bahkan keselip dan hilang.

Munculnya era paper less seharusnya mampu mentransformasi kehadiran sertifikat tersebut. Paper less tentunya tidak sama artinya dengan tanpa kertas. Paper less lebih tepat diartikan sebagai meminimalkan penggunaan dari kertas itu sendiri. Paper less diindentikan dengan hadirnya dokumen-dokumen digital yang dapat diakses secara mandiri (portable), mudah dan lintas platform.

Portable Document Format atau disingkat dengan PDF salah satu dokumen popular yang dapat distribusikan melalui internet. PDF file menjadi popular karena ukurannya yang relatif kecil dan ringan dalam pendistribusiannya melalui internet jika dibandingkan dengan format dokumen lainnya. Hingga saat ini telah banyak aplikasi pembaca dokumen PDF tersebut, bahkan hampir setiap browser sudah menyertakannya. Sehingga PDF dapat dijadikan sebagai basis dokumen untuk mewujudkan e-Certificate.

Membuat atau menghadirkan sebuah e-Certificate sudah seharusnya mampu mengatasi permasalahan yang ada pada sertifikat konvensional yang berbasis kertas. Beberapa permasalahan yang menjadi kekurangan dari sertifikat konvensional adalah mudah rusak (pudar hingga sobek), hilang, dan mudah dipalsukan (reproduksi). E-Certificate yang 
hadir dalam bentuk softcopy atau file dokumen akan mampu mengurangi permasalahan sertifikat yang rusak, pengarsipan file yang baik akan mampu mengurang permasalahan sertifikat yang hilang. Namun demikian permasalahan pemalsuan menjadi hal yang sulit untuk diatasi. Cara yang paling umum dilakukan pada sertifikat konvensional adalah mendeteksi keaslian tanda tangan dan ciri-ciri yang lain. Di era teknologi yang demikian pesat maka sertifikat konvensional bisa dibuat sangat mirip. Sehingga dengan demikian eCertificate harus juga melibatkan tanda tangan digital untuk menghadirkan solusi terkait dengan keaslian.

Pemerintah Indonesia sedang giat-giatnya melakukan perubahan dalam tata kelola penyelenggaraan pemerintahan, dari tata kelola penyelenggaraan pemerintahan konvensional menjadi tata kelola penyelenggaraan pemerintahan berbasis digital atau sering kita dengar sebagai e-government. Dengan dukungan kemajuan dalam bidang teknologi dan informasi yang berkembang dengan pesat saat ini, membuka peluang dalam hal pemanfaatan, pengelolaan, pendayagunaan dan pengaksesan informasi secara cepat dan akurat [1]. Di Indonesia sendiri terdapat produk hukum yang mendukung legalitas e-Certificate. Seperti PP menandatangani Peraturan Pemerintah (PP) Nomor 24 tentang Pelayanan Perizinan Berusaha Terintegrasi Secara Elektronik, tanda tangan elektronik disamakan dengan tanda tangan manual sebagaimana dijamin dalam penjelasan Pasal 11 UU ITE. Maka Pasal 1869 jo Pasal 1874 Kitab Undang-Undang Hukum Perdata dan Pasal 1 Ordonansi 1867 No. 29 juga berlaku pada tanda tangan elektronik sehingga dengan diberi tanda tangan elektronik maka dokumen elektronik tersebut memilki kekuatan hukum [2]. Salah satu tanda tangan elektronik yang dapat dimanfaatkan adalah QR Code. Bank Indonesia juga telah peraturan tentang pedoman implementasi Quick Response (QR) Code Indonesian Standard (QRIS). Pedoman itu tertuang dalam Peraturan Anggota Dewan Gubernur (PADG) No.21/18/PADG/2019 tentang Implementasi Standar Nasional Quick Response Code untuk Pembayaran pada 16 Agustus 2019 [3].

Penelitian ini akan pengembangan sebuah sistem e-Certificate untuk penyelenggaraan kegiatan di Universitas Kristen Maranatha, dengan mengimplementasikan tanda tangan digital berbasis QR Code sebagai jaminan keaslian e-Certificate yang dihasilkan. Keaslian eCertificate dilakukan dengan verifikasi QR Code yang terdapat pada e-Certificate.

\section{Metodologi Penelitian}

e-Certificate sendiri merupakan kependekan dari elektronik certificate atau sertifikat elektronik atau lebih dikenal dengan sertifikat digital. Terdapat penjelasan terkait eCertificate :

1. Sertifikat tersebut hadir dalam sebuah file dengan format dokumen tertentu (bisa PDF, atau file gambar) atau hasil pindaian. Tujuan sertifikat ini untuk menggantikan keberadaan sertifikat konvensional yang harus dicetak dalam media kertas tertentu.

2. Sertifikat tersebut juga hadir dalam bentuk file teks yang terenkripsi. File sertifikat ini menjadi suatu identitas yang dapat dimanfaatkan untuk suatu kegiatan atau transkasi pertukaran data yang aman. Dikatakan aman karena dalam enkripsi tersebut terdapat tanda tangan digital yang disertakan.

Dalam konteks penelitian ini maka yang dimaksud dengan e-Certificate adalah sebuah dokumen digital berformat PDF yang memiliki tanda tangan digital sebagai pengesahan dan untuk pengujian keaslian sertifikat tersebut. Tanda tangan yang digunakan berbasis pada $\mathrm{QR}$ Code.

QR Code adalah image berupa matriks dua dimensi yang memiliki kemampuan untuk menyimpan data di dalamnya. QR Code merupakan evolusi dari kode batang (barcode). Barcode merupakan sebuah symbol penandaan objek nyata yang terbuat dari pola batang-batang berwarna hitam dan putih agar mudah untuk dikenali oleh komputer [4]. Contoh sebuah QR Code dapat dilihat pada gambar 1. 


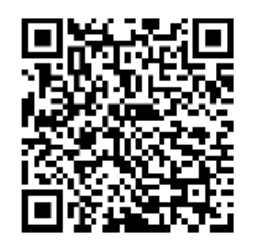

Gambar 1. Contoh QR Code

QR Code merupakan singkatan dari Quick Response Code, atau dapat diterjemahkan menjadi kode respon cepat. QR Code dikembangkan oleh Denso Corporation, sebuah perusahaan Jepang yang banyak bergerak di bidang otomotif. QR Code ini dipublikasikan pada tahun 1994 dengan tujuan untuk pelacakan kendaraan di bagian manufaktur dengan cepat dan mendapatkan respon dengan cepat. Prosedur pembangkitan QR Code [6] dari sebuah teks dapat dijelaskan dengan diagram pada gambar 2a. Langkah-langkah untuk untuk membaca QR Code [6] menjadi teks aslinya merupakan reverse atau kebalikan dari langkahlangkah pada pembangkitan QR Code. Secara umum prosedur pembacaan QR Code dapat dijelaskan dengan diagram pada gambar $2 \mathrm{~b}$.

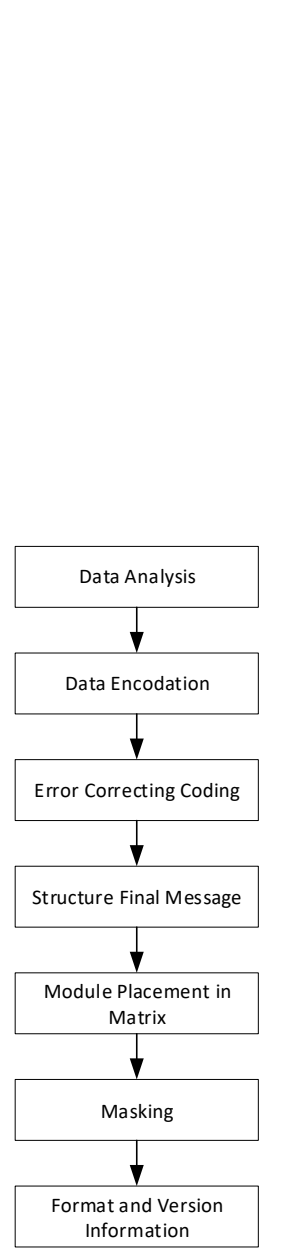

(a)

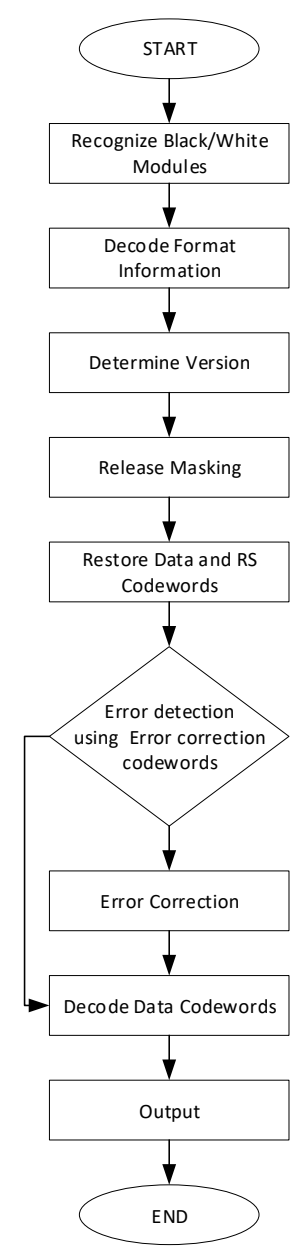

(b)

Gambar 2. (a) Diagram proses pembangkitan QR Code

(b) Diagram proses pembacaan QR Code 
Sistem e-Certificate diwujudkan dalam bentuk sebuah aplikasi berbasis web yang memiliki dua tugas utama yaitu: tugas pertama adalah menghasilkan e-certificate lengkap dengan QR Code dan tugas kedua adalah memverifikasi QR Code sehingga dapat dipakai untuk menguji keaslian sertifikat yang dihasilkan oleh aplikasi.

Use case diagram dari sistem ini (gambar 3) melibatkan tiga aktor yaitu administrator, personal in charge (PIC) dan pengguna yaitu dosen dan mahasiswa. Aktor administrator melakukan pengelolaan event dan input peserta event. Administrator di dalam lingkungan universitas dapat unit, lembaga, badan, fakultas hingga prodi. Aktor PIC adalah yang bertanggung jawab dalam penyelenggaraan event sekaligus yang mengesahkan sertifikat. Aktor pengguna melakukan pemilihan event yang pernah diikuti, mendownload sertifikat, dan dapat melakukan verifikasi keaslian sertifikat berdasarkan QRCode yang ada di sertifikat.

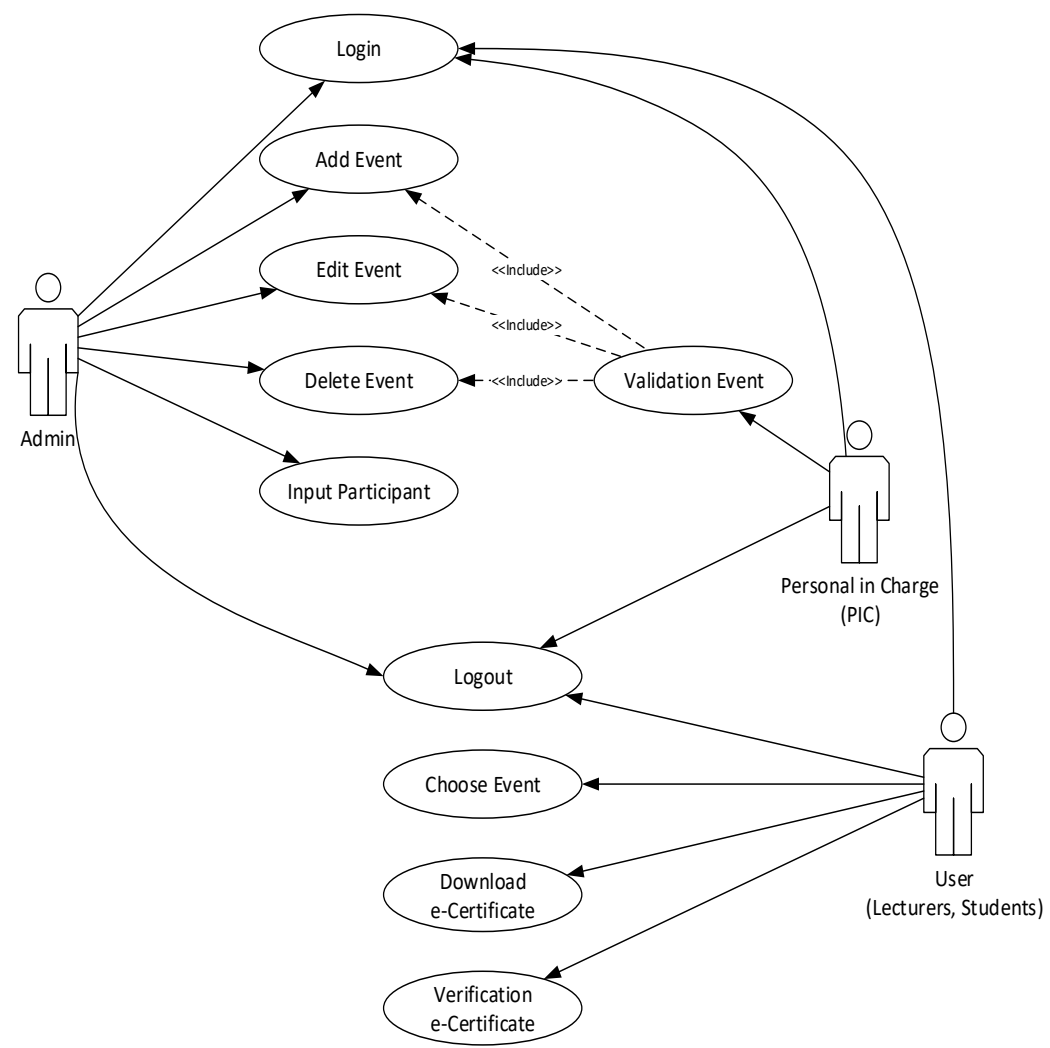

Gambar 3. Use Case e-Sertificate System

System e-Certificate yang dibuat melibatkan integrasi dengan sistem akademik terpadu (SAT) Universitas Kristen Maranatha. SAT merupakan pangkalan data dosen dan mahasiswa. Identitas dosen dan mahasiswa akan dapat diidentifikasikan dari sebuah nomor registrasi, untuk dosen adalah Nomor Induk Karyawan (NIK) dan mahasiswa adalah Nomor Registrasi Pokok (NRP). NIK dan NRP digunakan untuk login dalam sebuah SAT.

Web service (WS) dapat digunakan untuk melakukan pertukaran data yang memiliki beda platform [5]. SAT memiliki WS yang dapat digunakan dalam lingkungan pengembangan software di Universitas Kristen Maranatha. WS sebagai application programming interface (API), yang digunakan oleh System e-Certificate untuk berkomunikasi. System e-Certificate melakukan login dengan bantuan WS tersebut (gambar 4). 


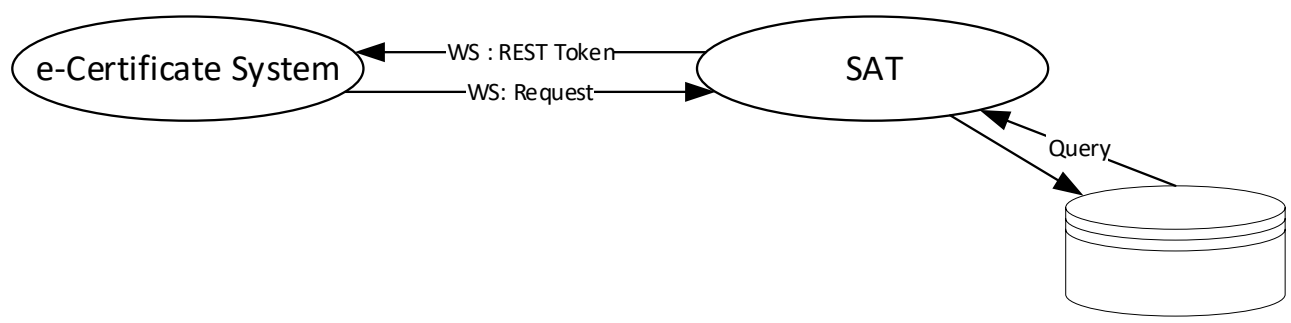

Gambar 4. Arsitektur e-Sertificate System

System dikembangkan dengan menggunakan pendekatan pola desain (design pattern) arsitektur pengembangan aplikasi MVC (Model, View, Controller). MVC membagi aplikasi ke dalam tiga bagian fungsional: model, view, dan controller (gambar 5).

1. Model adalah kode-kode untuk model bisnis dan data. biasanya berhubungan langsung dengan database untuk memanipulasi data (insert, update, delete, search), menangani validasi dari bagian controller, namun tidak dapat berhubungan langsung dengan bagian view. Model yang dibuat adalah untuk mendapatkan data sertifikat seperti event dan PIC dan verifikasi sertifikat.

2. View merupakan bagian yang menangani presentation logic. berisi kode-kode untuk tampilan. View yang dibuat adalah login, tampilan sertifikat, dan tampilan verifikasi

3. Controller merupakan bagian yang mengatur hubungan antara bagian model dan bagian view, controller berfungsi untuk menerima request dan data dari user kemudian menentukan apa yang akan diproses oleh aplikasi. Controler yang dibuat untuk berkomunikasi ke WS, menghasilkan QRCode dan kode kunci sertifikat, berkomunikasi dengan model dan view.

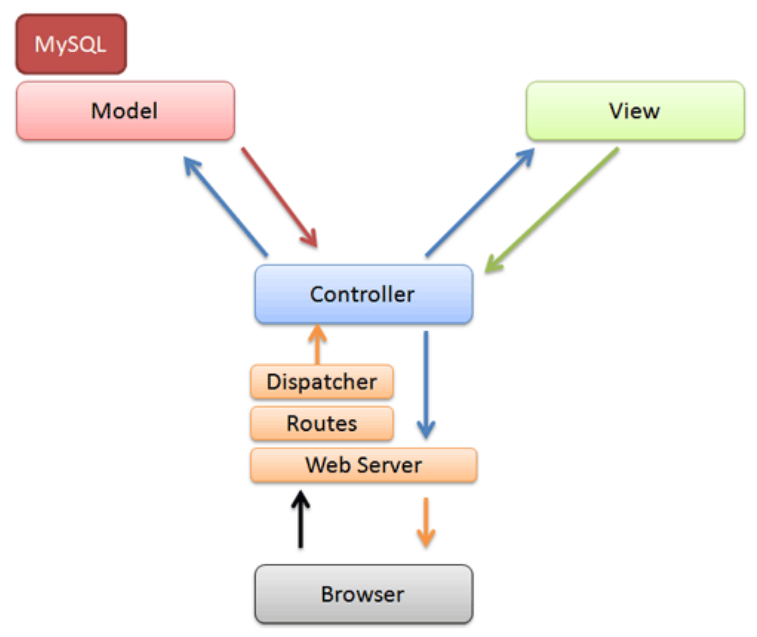

Gambar 5. MVC e-Sertificate System

\section{Hasil dan Pembahasan}

Dalam aplikasi yang dibuat maka untuk implementasi system e-Certificate di wujudkan dalam dua proses yaitu : memperoleh sertifikat dan menguji keaslian dari sertifikat yang dihasilkan (gambar 6a). Proses memperoleh melewati lima tahap, diawali dari data event yang dipilih hingga pada akhirnya menghasilkan e-certificate. Bagian yang penting dalam proses ini adalah tahap menghasilkan key protection yang terdiri dari 5 karakter acak kombinasi angka dan huruf dan tahap menghasilkan QR Code yang berisi informasi untuk verifikasi. 

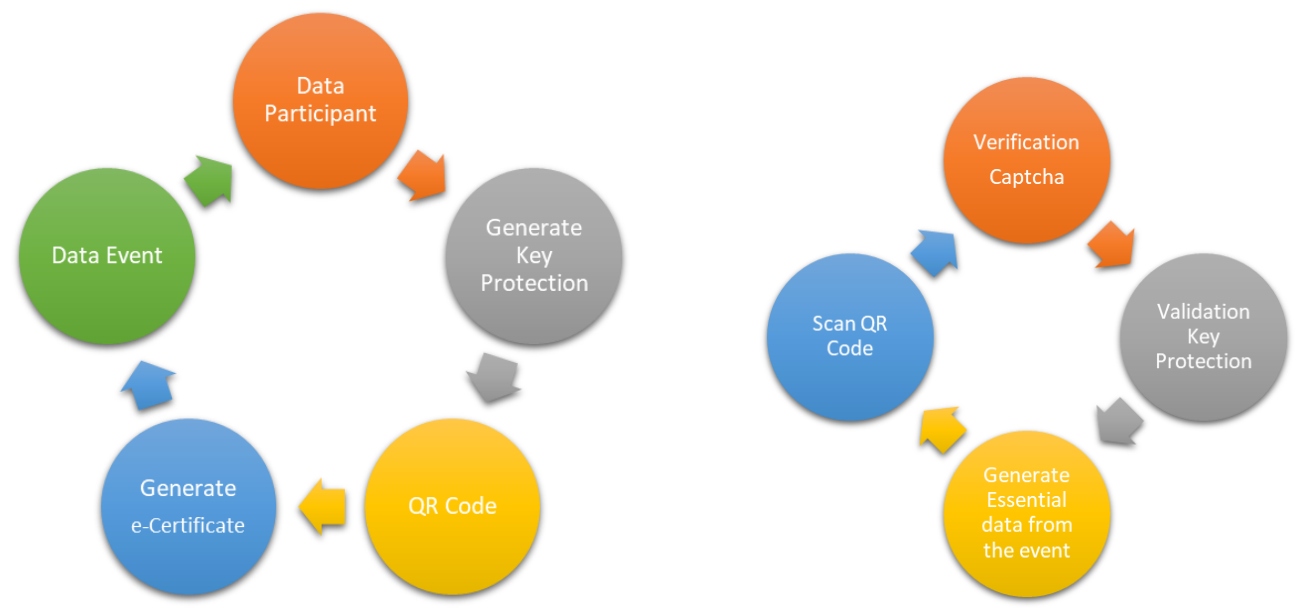

(a) (b)

Gambar 6. (a) Tahap-tahap menghasilkan e-Certificate

(b) Tahap-tahap menguji keasliasn e-Certificate

Key protection merupakan kombinasi data event dan pengguna yang kemudian dilakukan proses hashing (bagian dari teknik digest) selenjutnya dilakukan proses enkripsi kemudian secara random diambil 5 karakter sebanyak 2 kali. 5 karakter pertama akan digunakan untuk menghasilkan QR Code dan kemudian 5 karakter selanjutnya di letakkan di bagian bawah QR Code. Key protection digunakan dalam proses verifikasi keaslian ecertificate. Ilustrasi terkait dengan key protection seperti pada gambar 7 .

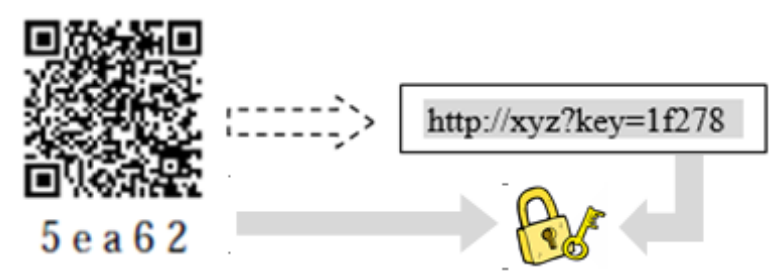

Gambar 7. Key Protection pada e-Certificate

Proses pengujian keaslian sertifikat (gambar 6b) dimulai dari scan QR Code diikuti dengan verifikasi captcha dan kemudian dekripsi kedua kunci yang ada di QR Code dan 5 karakter yang diletakkan berada di bawah QR Code. Hasil dari proses verifikasi akan memunculkan informasi penting terkait informasi seminar dan peserta yang mengikuti. Jika terjadi ketidak aslian maka akan muncul informasi sertifikat tidak valid. Implementasinya pada aplikasi untuk menghasilkan e-certificate, diawali dari proses login hingga proses download sertifikat. Gambar 6b menujukan urutan tahap dalam proses ini. 

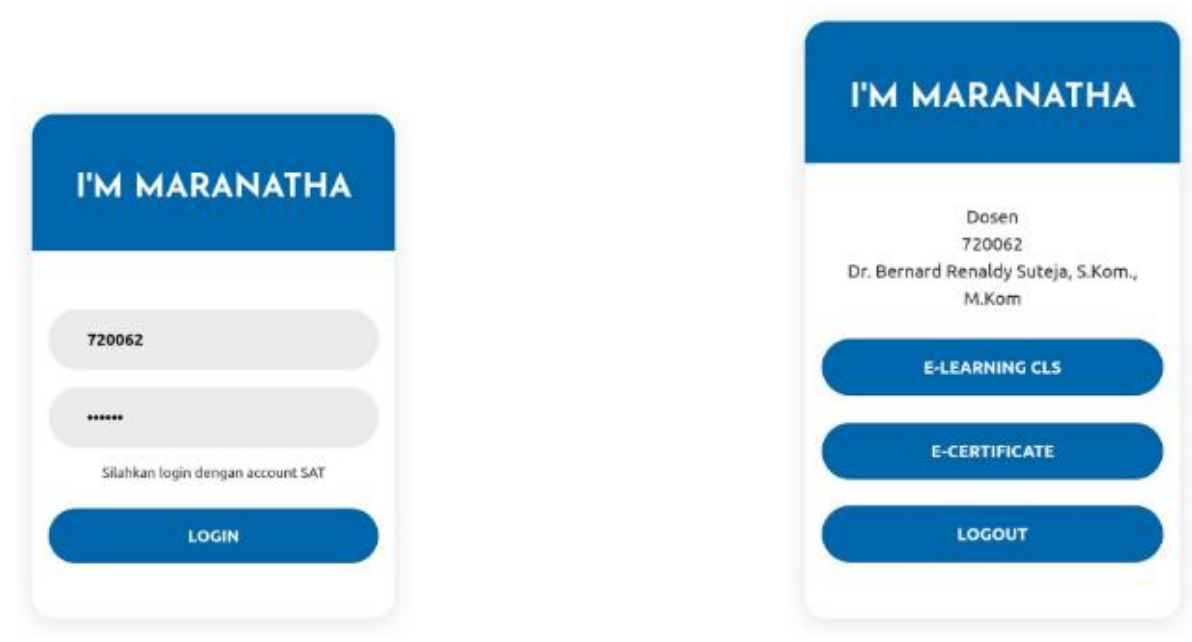

(a) (b)
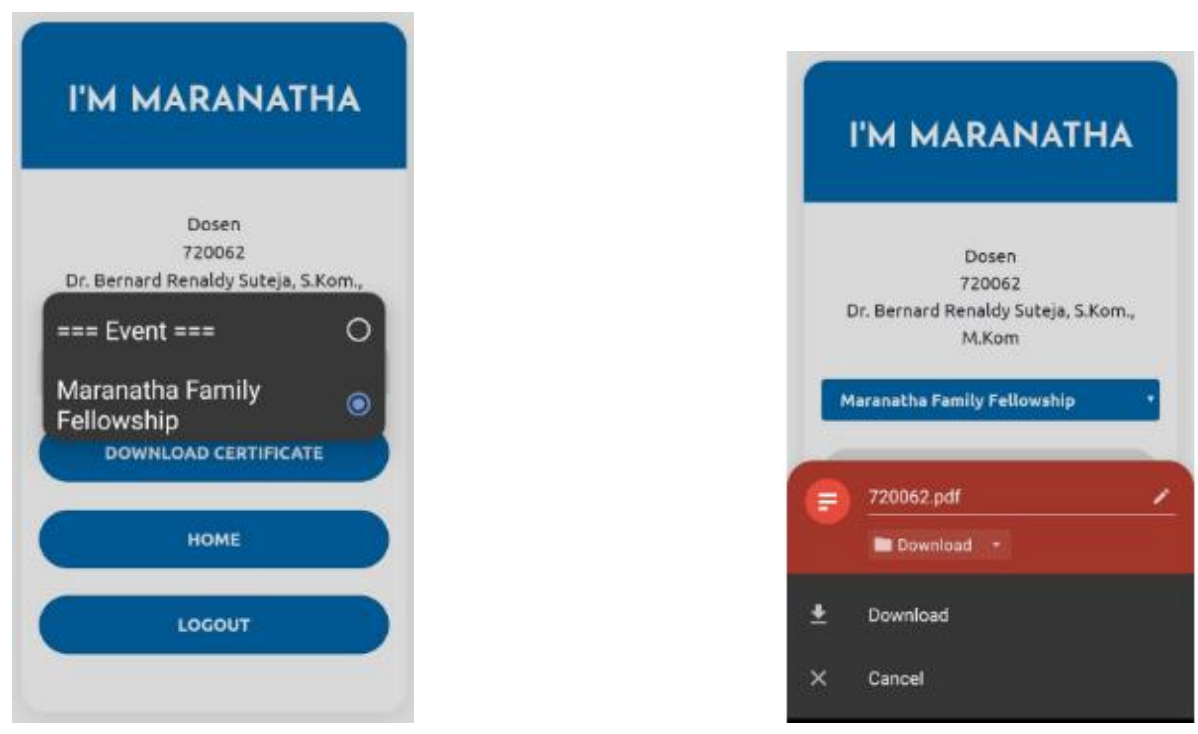

(b) (d)

Gambar 8. Urutan user interface memperoleh e-Certificate

E-Certificate yang dihasilkan oleh aplikasi ini (gambar 9) telah melalui proses kompresi yang baik sehingga tidak mengurangi kualitas baik image dan karakter yang tertera. E-Certificate yang dihasilkan melalui aplikasi memiliki ukuran file kurang dari $50 \mathrm{~Kb}$ (gambar 10). Hasil dari e-certificate yang telah didownload seperti gambar 12 dapat dilakukan pengujian keasliannya. Pengujiannya dengan melakukan pemindaian QR Code dengan aplikasi QR Code reader apapun. 


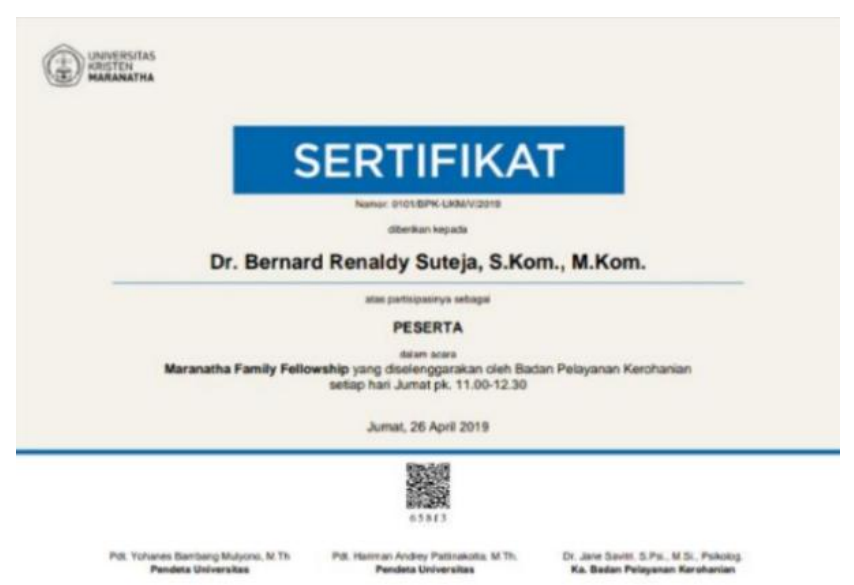

Gambar 9. Contoh e-Certificate

Pengujian e-Certificate dilakukan dengan memindai QR Code yang ada di eCertificate. Dengan melalui tahap verifikasi maka jika sertifikat tersebut tidak sesuai dengan key protection yang telah disertakan maka sertifikat tersebut dinyatakan palsu.

\section{I'M MARANATHA}

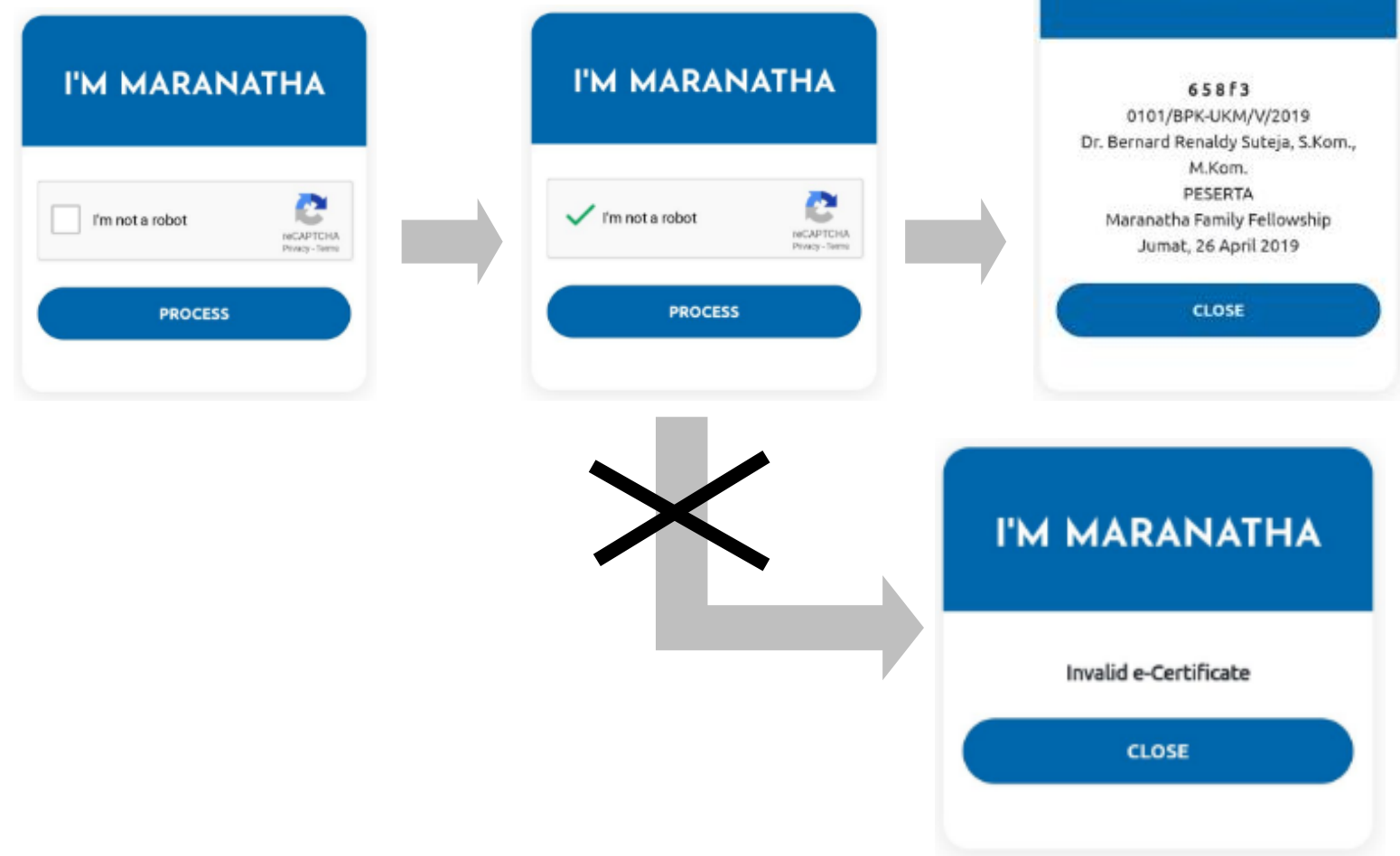

Gambar 10. Urutan user interface verifikasi e-Certificate 


\section{Kesimpulan}

Sistem e-Certificate telah dapat diimplementasikan kedalam sebuah aplikasi. Aplikasi dapat menghasilkan sebuah e-Certificate yang aman dengan double protection sesuai dengan event yang diikuti oleh seorang peserta baik dosen atau mahasiswa Universitas Kristen Maranatha. E-Certificate dapat didownload dan dicetak untuk keperluan yang dibutuhkan oleh peserta. Pengujian keaslian e-Certificate juga dapat dilakukan dengan baik.

\section{Daftar Pustaka}

[1] Nugraha, A. dan Mahardika A., Penerapan Tanda Tangan Elektronik pada Sistem Elektronik Pemerintahan Guna Mendukung E-Government. Seminar Nasional Sistem Informasi, 2016.

[2] Angel Firstia Kresna, Legalitas Tanda Tangan Elektronik Pejabat Dalam Rangka Mendukung E-Government, https://www.mahkamahagung.go.id/id/artikel/3737/ legalitas-tanda-tangan-elektronik-pejabat-dalam-rangka-mendukung-e-government, diakses Senin, 4 November 2019 13:03 WIB

[3] Bank Indonesia, QRIS, Satu QR Code untuk Semua Pembayaran, https://www.bi.go.id/id/ruang-media/siaran-pers/Pages/SP_216219.aspx, diakses Selasa, 5 November 2019 10:50 WIB

[4] Law, C. Y., \& So, S. (2010). QR codes in education. Journal of Educational Technology Development and Exchange (JETDE), 3(1), 7.

[5] Suteja, B. R. (2018). Pencarian Content Portal Web Berita Dengan Teknik Sindikasi Berbasis Ajax-Soap Web Service. Compiler

[6] Herlina, E., \& Hidayatulloh, T. (2017). Penerapan QR Code Untuk Sistem Absensi Siswa SMP Berbasis Web. Jurnal Teknologi dan Informasi, 7(2). 
Bernard Renaldy Suteja, Radiant Victor Imbar, Meliana Christianti Johan 